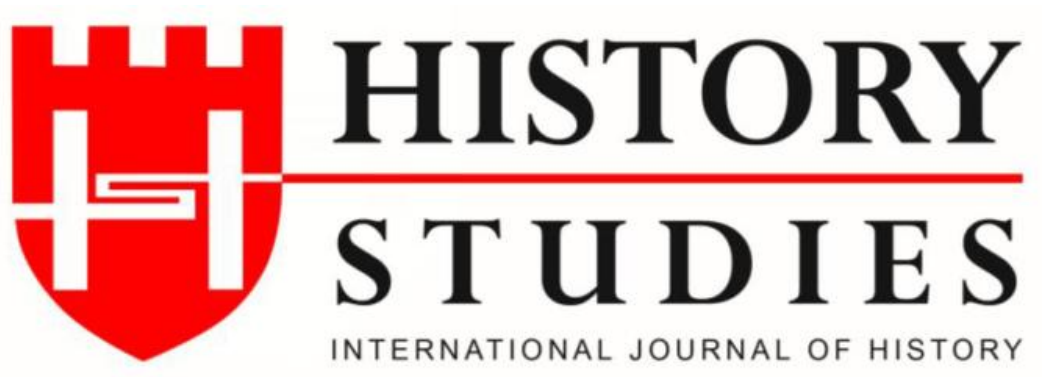

ISSN: 13094173 (Online) 1309 - 4688 (Print)

Volume 12 Issue 3, June 2020

DOI Number: 10.9737/hist.2020.851

Araştırma Makalesi

Makalenin Geliş Tarihi: 27.04.2020 Kabul Tarihi: 12.05.2020

Atıf Künyesi: Ahmet Efiloğlu, "Ayvalık Rumlarının Tehciri", History Studies, 12/3, Haziran 2020,

s. 727-743.

\title{
Ayvalık Rumlarının Tehciri
}

The Deportation of the Ayvallk Greeks

\author{
Doç. Dr. Ahmet Efiloğlu \\ ORCID No:0000-0002-0294-5943 \\ Zonguldak Bülent Ecevit Üniversitesi
}

Volume 12

Issue 3

June

2020

Öz: Ayvalık, Batı Anadolu'da, nüfusunun tamamına yakını Rumlardan oluşan yerleşim merkeziydi. Batı Anadolu'da Yunan milliyetçiliğinin önemli merkezlerinden olan Ayvalık'ta Rumlar, Balkan Savaşı ve I. Dünya Savaşı sırasında Osmanlı Devletinin savaştığı devletlere destek olmuşlardı. Rumların her iki savaşta, Çanakkale Boğazına yakın olduğu için, boğaz güvenliği açısından önemli bir konumda bulunan Ayvalık'ta, devlet ve Müslüman ahali aleyhine zararlı faaliyetlerini arttırmaları burada çok ciddi güvenlik sorunlarının ortaya çıkmasına neden olmuştu. Bundan dolayı, cephelerde yoğun bir çarpışma içerisinde olan Osmanlı ordusu, burada yaşanabilecek bir askeri çıkarmaya karşı önlemlerini arttırmak zorunda kalmıştı.

Ayvalık'n her iki savaşta Anadolu güvenliğini tehdit eden bir yer haline gelmesi İttihat ve Terakki'nin burada yaşayan Rumları güvenilmez unsur olarak görmelerine neden olmuştu. Hükümet bu bakış açısıyla hareket ederek 1914'den itibaren Ayvalık Rumlarının sebep olduğu tehlikeyi en aza indirmek için harekete geçti. Yunanistan'ın buraya saldırma ihtimalini en aza indirerek güvenliğin sağlanması için, hükümetin aldığı en önemli karar Rumların buradan göç ettirilmesiydi. Ancak bu göç ettirme ülke dışına yani Yunanistan'a ve Yunanistan'ın eline geçmiş olan Ege adalarına doğru olacaktı. Bu yöntemle Ayvalık'ta Rum nüfusu azaltılarak Yunanistan'ın buraya asker çıkarma ihtimali azaltılmış olacaktı. Hükümet Dünya Savaşı sırasında da burada tehcir uygulamasına devam edecek, Rumları ülke içerisinde başka yerlere göç ettirerek Ayvalık’ı tamamen boşaltacaktı.

Anahtar Kelimeler: Ayvalık, Rumlar, Tehcir, Balkan Savaşı, I. Dünya Savaş1

Abstract: Ayvalık was a settlement center in Western Anatolia whose population almost all consisting of Greeks. Greeks supported the states where the Ottoman Empire fought during the Balkan War and the First World War in Ayvalık which was one of the important centers of Greek nationalism in Western Anatolia. Since the Greeks were close to the Dardanelles in both wars and because the fact that Ayvalık has an important position in terms of strait security, they increased the harmful activities against the state and the Muslim community and caused serious security problems there. For this reason, the Ottoman army, which was in an intense clash on the fronts, had to increase its precautions against a military deployment that could be experienced here.

The fact that Ayvalık became a place threatening Anatolian security in both wars caused the Union and Progress to see the Greeks living here as unreliable element. The government, acting from this perspective, has taken action to minimize the danger caused by Ayvalık Greeks since 
1914. The most important decision taken by the government to ensure security by minimizing the possibility of Greece attacking here was to migrate the Greeks from here. However, this immigration would be out of the country, that is, towards Greece and the Aegean islands that were taken over by Greece. By using this method, the Greek population in Ayvalık would be reduced and the possibility of Greece taking troops here would be reduced. The government would continue deportation here during World War and would migrate the Greeks to other places in the country and evacuate Ayvalık completely.

Keywords: Ayvalık, Greeks, The Deportation, Balkan War, World War I

\section{Giriş}

İttihat ve Terakki'nin 1914'ten 1918'e kadar olan süreçte Rumlara karşı uyguladığ politikalardan en dikkat çekeni tehcirdir. Balkan Savaşından sonra uygulanmaya başlanan Rum tehciri I. Dünya Savaşının sonuna kadar devam etmişti. 1914 yılında uygulanan göç ettirmelerle Trakya, Marmara Denizi sahilleri ve Batı Anadolu sahil kesimlerinde yaşayan Rumların önemli bir kısmı Yunanistan’a ve Yunanistan’ın Balkan Savaşında ele geçirdiği Ege adalarına göç ettirilmişti. Birinci Dünya Savaşı sırasında uygulanan tehcirlerle de önemli miktarda Rum nüfusu ülke sınırları içerisinde zorunlu sevk ve iskana tabi tutulmuştu.

İttihat ve Terakki hükümetinin bu dönemde tehcir uyguladığı önemli yerlerden bir tanesi de Ayvalık'tı. Burası coğrafi konumu itibariyle Çanakkale Boğazına yakın olduğundan stratejik öneme sahipti. Ayrıca şehrin nüfusunun tamamına yakınını Rumlar oluşturmaktaydı ve Rumlar arasında Yunan milliyetçiliği çok yaygındı. Rumlar Balkan Savaşında ve Birinci Dünya Savaşında Osmanlı Devletinin savaştı̆̆ı devletlere destek olmuşlardı. İttihat ve Terakki hükümeti de Anadolu'nun güvenliğini sağlamak amacıyla tehcir uygulamıștı. Bu çalışmada arşiv malzemeleri kullanılarak Ayvalık'ta iki dönem halinde uygulanan tehcir ve tehcir sırasında yaşanan sorunlar ortaya konulmaya çalışılacaktır.

\section{1-Balkan Savaşı Sonrası Batı Anadolu Rumlarının Göç Ettirilmeye Başlanması}

Osmanlı Devletinin çok ağır bir yenilgi alarak Balkan topraklarını kaybedip Anadolu’ya çekilmek zorunda kaldığı Balkan Savaşı, her anlamda Osmanlı Devletini derinden etkilemişti. Savaş sırasında meydana gelen hadiseler ve savaşın neden olduğu sorunlar İttihat ve Terakki hükümetinin savaş sonrasında uygulayacağı bütün politikaları derinden etkileyecekti. Bu etkinin kendisini hissettirdiği alanlardan birisi de Rum politikasıydı.

Balkan Savaşı sırasında özellikle Trakya ve Anadolu'da yaşayan Rumların tutum ve davranışları, hükümetin Rumlara bakışının değişmesine neden olacaktı. Savaş sırasında Trakya'da yaşayan Rumlar bir yandan buraları işgal eden Bulgar ordusuyla birlikte hareket etmişler, diğer yandan da Müslüman ahaliye karşı büyük katliamlar yapmışlardı. Savaş alanı dışında Marmara ve Ege Denizi sahillerinde yaşayan Rumlar da farklı değillerdi. Onlar da yürütmüş oldukları zararlı faaliyetlerle cephe gerisinde devleti zaafa düşürerek yenilmesini sağlamaya çalışıyorlardı. Trakya'daki Rumlar Bulgar ordusuyla birlikte hareket ettiği gibi Batı Anadolu sahil kesiminde yaşayan Rumlar da Ege Denizini kontrol altına alan Yunan donanmasına destek oluyorlardı. Ayrıca Yunanistan’ın Ege adalarını işgal etmesine yardım ediyorlardı. Adalara giderek Yunan askerleri ile birlikte oralarda yaşayan Müslüman ahaliye katliam yapıyorlard1. ${ }^{1}$

Savaş sırasında Rumların Osmanlı Devletinin ve Müslüman ahalinin aleyhine bu şekilde açıktan çalışmış olmaları, hükümetin Rumlara karşı çok büyük bir tepki duymasına neden olmuştu. Bu zararlı faaliyetlerle Rumlar artık İttihatçıların nazarında güvenilmez bir unsur

${ }^{1}$ Ahmet Efiloğlu, Osmanlı Rumları Göç ve Tehcir 1912-1918, Bayrak Yay., İstanbul 2011, s.31-64. 
olarak görülmekteydiler. Hatta yeni bir savaşta aynı şekilde davranmaları muhtemel görüldüğünden Anadolu güvenliği için tehdit olarak algılanmaktaydılar. İttihatçılar sahip oldukları bu bakış açısıyla Rumları göç ettirmeye karar vereceklerdi. ${ }^{2}$

İttihat ve Terakkinin Rum politikasının şekillenmesinde belirleyici rol oynayan ikinci etken Osmanlı Devleti ile Yunanistan arasında yaşanan sorunlardı. İki devlet arasında yaşanan sorunların başında Müslüman göçü gelmekteydi. Savaşın başından itibaren Makedonya'dan Müslümanları göç ettiren Yunanistan İttihat ve Terakkinin bütün tepkilerine rağmen bundan vazgeçmiyordu. Yunanistan'ın bu tutumu karşısında İttihat ve Terakki Yunanistan'a karşı mukabele-i bil'mislde bulunma yani aynı şekilde karşılık verme kararı almıştı. Rumlar göç ettirilerek Yunanistan'a geri adım attırmak isteniyordu. ${ }^{3}$

Osmanlı Devleti ile Yunanistan arasında yaşanan bir diğer sorun Ege Adaları meselesiydi. Yunanistan Balkan Savaşı sırasında Ege Adalarını işgal etmişti. Megali İdeayıyı gerçekleştirmek için yayılmacı politikalarına devam eden ve Anadolu'ya çıkma planları yapan Yunan hükümeti, ele geçirdiği adaları hiçbir şekilde Osmanlı Devleti'ne bırakmayı düşünmüyordu. Buna karşın İttihat ve Terakki hükümeti de Anadolu'nun güvenliğini tehlikeye sokacağı endişesiyleBatı Anadolu sahillerine çok yakın olan Ege Adalarını Yunanistan'a bırakmak istemiyordu. İttihat ve Terakkinin bütün itirazlarına rağmen Büyük Devletler 14 Şubat 1914'te adaların Yunanistan'a bırakılmasına karar verdiler. İttihat ve Terakki Büyük Devletlerin kararını kabul etmediğini ilan etti. Neticede 1914'ün başlarından itibaren Ege Adaları sorunu nedeniyle iki devlet tekrar bir kere daha karşı karşıya geldi. Hatta bu sorun nedeniyle iki devlet arasında yeni bir savaş çıkma ihtimali konuşulmaya başlanmıştı. İttihat ve Terakki hükümeti yeni bir savaşı göze alamasa da Yunanistan'ın saldırma ihtimaline karş1 hazırlık yapmaya başlamıştı. Hükümet bir yandan Batı Anadolu'da askeri düzenlemeler yapıyor diğer yandan da yeni savaş gemileri satın alınmaya çalışıyordu. Hükümet Yunan tehlikesinin kendisini iyice hissettirdiği bu atmosferde Batı Anadolu'da yaşayan ve Yunanistan'la iş birliği içinde olan Rumlara karşı da tedbir almayı Anadolu'nun güvenliği açısından gerekli görmekteydi. Hükümete göre alınacak tedbir Batı Anadolu'nun sahil kesimlerinde yaşayan Rumların göç ettirilmesiydi. ${ }^{4}$

Tüm bu gelişmelerin sonucunda İttihat ve Terakki hükümeti 1914 yılı başlarında Rumları göç ettirmeye karar vermişti. ${ }^{5}$ Ancak resmi bir kararla Rumların göç ettirilmesi, Yunanistan ile yapılacak yeni bir savaşın sebebi olabilirdi. Ayrıca böyle resmi bir göç ettirme uygulaması Avrupa'yı da ayağa kaldırabilirdi. Bundan dolayı Rumlara karşı gayrı resmi bir göç ettirme politikası uygulanacaktı. Yani çeşitli uygulamalarla Rumların kendi istekleri ile göç etmeleri sağlanacaktı. Planlamaya göre parti teşkilatlarındaki görevlilerin, Teşkilatı Mahsusacıların dışında memurlar organizasyonun içinde olmayacaklardı. ${ }^{6}$

\footnotetext{
${ }^{2}$ Celal Bayar, Ben de Yazdım, C. V, s. 1572-1580; Y Doğan Çetinkaya, Osmanlı'yı Müslümanlaştırmak, İletişism Yayını, İstanbul 2015, s.171.

${ }^{3}$ Efíloğlu, age, s. 195.

${ }^{4}$ Ahmet Efiloğlu, age, s.197-198; Halil Menteşe'nin Anıları, Osmanlı Mebusan Meclisi Reisi, Haz.: Orhan Birgit, Hürriyet Vakf1, İstanbul 1986, s.165; Bayar, age, s. 1572-1580; Cemal Kutay, Etniki Eteryadan Günümüze Ege'nin Türk Kalma Savaşı, Boğaziçi Yay., İstanbul 1980, s.206-2113; Nurdoğan Taçalan, Ege'de Kurtuluş Savaşı Başlarken Hasan Tahsin, Aksoy Yay., İstanbul 1998, s.51-53.

5 Emre Erol, “Makedonya Sorunu'nun Batı Anadolu'ya Siçrayışı ve 1914 Rum Tehciri”, Toplumsal Tarih, S. 252, Aralik 2014, s.58-65.

${ }^{6}$ Taner Akçam, Ermeni Meselesi Hallolmuştur, Osmanlı Belgelerine göre savaş yıllarında Ermenilere Yönelik Politikalar, İletişim Yay., İstanbul, 2008, s.86; Fuat Dündar, Modern Türkye'nin Şifresi İttihat ve Terakkinin Etnisite Mühendisliği (1913-1918), İletişim Yay., İstanbul 2008, s.197-203.
} 
İttihat ve Terakki hükümeti bu şekilde Batı Anadolu Rumlarını 1914'ün ilkbahar aylarında göç ettirmeye başlamıştı. Özellikle İzmir' in sahil kesimlerinde yer alan ve nüfusunun tamamına yakını Rum olan Kuşadası, Karaburun, Foça ${ }^{7}$, Çeşme gibi yerleşim yerlerinin boşaltılmasına çalışılıyordu. Sahil kesiminde başlayan göç hareketliliği kısa zaman içinde iç kesimlere doğru yayılacakt1.

\section{2-Ayvalık Rumlarının Göç Ettirilmesi}

Batı Anadolu'da İzmir ve çevresinden sonra Rumların göç ettirildiği önemli merkezlerden bir tanesi de Ayvalık'tı. Bunun da sebebi hiç şüphesiz nüfusunun tamamına yakınını Rumların oluşturduğu Ayvalık'ın, Balkan Savaşı sırasında zararlı faaliyetlerin yoğunlaştığı bir yer haline gelmiş olmasıydı. Savaş sırasında Rumlar, Ayvalık sahillerini ablukaya alarak asker ve çetelerle saldıran Yunan ordusuna destek vermişlerdi. Ayrıca bu çevredeki Müslüman ahaliyi bask1 altına almışlar, gizlice silahlanmışlar, Midilli adasına giderek Yunan askerlerinin ve çetelerinin yaptıkları Müslüman katliamlarına karışmışlardı. Rumların Yunan milliyetçisi olmaları ve Yunanistan'ı açıktan desteklemiş olmaları, Yunanistan'ın buraya asker çıkarma ihtimalini kuvvetlendirmişti. İttihat ve Terakki hükümeti Yunanistan'ın karaya asker çıkarma tehlikesinden dolayı buradaki askeri önlemeleri arttırmak zorunda kalmıştı. ${ }^{8}$

Hükümetin Balkan Savaşından sonra Ayvalık'a bakışında herhangi bir değişiklik olmamıştı. 1914'ün başlarından itibaren Osmanlı Devleti ile Yunanistan arasında yeni bir savaş ihtimali gündeme geldiğinde, Ayvalık yine Yunanistan'ın Batı Anadolu'da ilk saldıracağı yer olarak değerlendiriliyordu. ${ }^{9}$ Hükümetin bakış açısına göre, Çanakkale Boğazının güvenliğinin sağlama alınabilmesi için Rumların göç ettirilmesi, buna eş zamanlı olarak da sevk edilecek muhacirlerle buradaki Türk-Müslüman nüfusun arttırılması gerekiyordu.

Ayvalık'taki hadiseler de Batı Anadolu'nun diğer yerlerinde olduğu gibi 1914 yılının Mayıs ayında başlamıştı. Rumları göç ettirmek için burada da aynı yöntemler uygulanıyordu. ${ }^{10}$ Yöntemlerden ilki muhacir iskanıydı. Bu çevreye de Balkanlardan göç ettirilen muhacirler iskan ediliyordu. Ayrıca Midilli adasının hemen karşısında olduğu için orada Yunan asker ve çetelerinin saldırı ve katliamlarından kurtulabilen muhacirlerin de en çok geldiği yer Ayvalık'tı. ${ }^{11}$ Gelen muhacirler yaşadıklarının intikamını almak için Rumlara saldırıyorlardı. ${ }^{12}$ Yerel idareciler Rumların göç etmeye karar vermelerini sağlayabilmek ${ }^{13}$ için özellikle Laz muhacirleri de buraya sevk ve iskan ediyorlardı. ${ }^{14}$ Bundan başka Ayvalık’ta Rumları göç ettirmek için kullanılan bir diğer yöntem boykottu. ${ }^{15}$ Çok sert bir şekilde uygulanan boykot

\footnotetext{
${ }^{7}$ Emre Erol, “Eski Foça'nın 'Kara Haziran'1”, Toplumsal Tarih, S.248, Ağustos 2014, s.86-90.

${ }^{8}$ Efiloğlu, age, s.45-48, 86-87.

${ }^{9}$ Age, s.47.

${ }^{10}$ BOA (Devlet Arşivleri Başkanlığı Osmanlı Arşivi) Dahiliye Nezareti Şifre Kalemi (BOA. DH.ŞFR), 464/57, 8 Mart 1914 (23 Şubat 1330).

${ }^{11}$ Ahmet Halaçoğlu, Balkan Harbi Sırasında Rumeli'den Türk Göçleri, TTK Yay., Ankara 1995, s.116.

12 BOA Harici Nezareti Siyasi Kısım (BOA. HR.SYS), 1961/20, 11 Eylül 1914 (28 Eylül 1330); BOA. DH.ŞFR, 42/65, 18 Haziran 1914 (5 Haziran 1330).

${ }^{13}$ BOA Dahiliye Nezareti İdare (BOA. DH.ID), 176/24, 17 Kasım 1912 (4 Teşrini Sani 1329); BOA. HR.SYS, 1961/20, 11 Ekim 1914 (28 Eylül 1330); BOA. Dahiliye Nezareti Emniyeti Umumiye Müdüriyeti Emniyet Kalemi (DH.EUM.EMN), 64/25, 9 Aralı 1913 (26 Teșrini Sani 1329); Persecution of the Greeks in Turkey 1914-1918, Greek Patriarchate, Constantinaoble 1919, s. 66.

${ }^{14}$ Fuat Dündar, İttihat ve Terakkinin Müslümanları İskan Politikası (1913-1918), İletişim Yay., İstanbul 2001, s. 157.

${ }^{15}$ Çetinkaya, age, s.209-226
} 
neticesinde Rumlar hem ekonomik sıkıntı yaşamaya başlamışlar, hem de büyük bir korku içinde kalmışlardı. ${ }^{16}$ Hayat şartlarının zorlaşması Rumları göç etmeye zorluyordu.

Muhacir iskanı ve boykotun yanında Ayvalık Rumlarının korku içinde kalmalarının bir diğer sebebi de Kuşçubaşı Eșref'ti. ${ }^{17}$ Harbiye Nazırı Enver Paşa tarafından Batı Anadolu Rumlarını göç ettirmek üzere görevlendirilen Teşkilatı Mahsusacı Kuşçubaşı Eşref ,Ayvalık’ta da faaliyette bulunuyordu. Burada Rumları korkutmak için 1827 Yunan isyanı sırasında, isyana destek verdikleri için Ayvalık'ın zeybekler tarafından basılması olayını tekrar hatırlatırcasına, birkaç hafta üst üste Rumlar kiliselerde ayin yaparlarken belleri silahlı zeybekleri şehirde gezdirtip, gövde gösterisi yaptırtıyordu. Kuş̧̧ubaşı Eşrefin hatıratında bu zamanda yapılanlardan övgüyle bahsedilecektir. ${ }^{18}$

Batı Anadolu'da Yunan düşüncesinin önemli merkezlerinden olan Ayvalık'ta meydana gelen bu hadiseler Yunan kamuoyunda çok büyük bir tepkiye neden olmuştu. Yunan hükümeti, İttihat ve terakki hükümetini Rumları göç ettirmekle suçluyordu. İttihat ve Terakki hükümeti gayrı resmi bir göç ettirme politikası uyguladığı için Rumların Balkanlardan göç ettirilen Müslüman muhacirlerle aralarında yaşadıkları sorunlardan dolayı kendi istekleri ile göç ettiklerini ileri sürerek kendisini savunmaya çalışıyordu. Buna karşın Yunan hükümeti, Rum göçünün, İttihat ve Terakkinin bir uygulaması olduğunu ortaya koymak için, Osmanlı askeri ve sivil memurlar tarafından Rumlara yapıldığını iddia ettiği saldırı ve kötü muamelelere yönelik şikayetleri dile getiriyordu.

Örneğin, Dâhiliye Nezareti 12 Mayıs 1914 tarihli telgrafında Karesi Mutasarrıflığına Yunan Sefaretinin, kıyafet değiştirmiş bir takım askerlerin eşkıya ile birlikte Ayvalık'ta dolaştıkları, şehri kuşattıkları ve şehre saldırmakla tehdit ettikleri, şehre erzak girişlerinin engellendiği şikâyetlerini bildirmişti. ${ }^{19}$

Volume 12

Yine Dahiliye Nezareti, Karesi Mutasarrıflığına gönderdiği 8 Haziran 1914 tarihli başka bir telgrafında Yunan Sefaretinin; Ayvalık ve Edremit Kaymakamlarının Rumları göç etmeye zorladıklarından, bu kaymakamların Türk eşrafını Rumları göç ettirmeye teşvik ettiklerinden; kendi arzuları ile göç ettiklerine dair Rumlardan imzalı kâğıtlar alındığından; jandarmaların yardım istemek amacıyla Ayvalık Kaymakamlığına sığınan Rumlara engel olduklarından; askeri komutanların teşvik ve yönlendirmeleri ile çıkan olaylarda Rumlardan ölenlerin olduğundan; Rum köylerine saldırılar meydana geldiğinden, zorla iskan edilen muhacirlerin Rumlara zulmettiklerinden; Rumların ve Yunan vatandaşı olanların mallarına saldırılar meydana geldiğinden, Rumları katletmek üzere İzmir Hapishanesi müdürünün başkanlığı altında çeteler oluşturulduğundan, bu çetelerin Ayvalık'a saldıracaklarından; kiliselerin Müslüman ahali tarafından saldırıya uğradığından ve eşyalarının çalındığından şikayet ettiğini bildirilmişti. ${ }^{20}$

Ayvalık Yunan Konsolosu Çerebis de kılık-kıyafet değiştirmiş subayların organize ettikleri başıbozukların Bergama'dan Edremit'e kadar olan alanda düzenledikleri saldırılarla Rumları korkutarak kaçırttıklarını, Jandarma Komutanının 11 Haziranda Ayazment'e saldırma kararı aldığını fakat İstanbul'dan gelen emirle saldırıyı ertelediğini iddia etmekteydi. ${ }^{21}$

\footnotetext{
${ }^{16}$ Efiloğlu, age, s. 133-142; Alexander Papadopoulus, Resmi Belgelerle Avrupa Savaşından Önce Türkiyeli Rumlar üzerindeki Zulüm Pontus Trajedisi 1914-1922 Kara Kitap, Pencere Yay., İstanbul 2013, s.14.

${ }^{17}$ Benjamin C. Fortna, Kuşçubaşı Eşref, Efsana Teşkilat-ı Mahsusa Subayının Hayatı, Çev: Selçuk Uygur, Timaş Yay., İstanbul 2018, s.202-208.

${ }^{18}$ Kutay, age, s.223.

${ }^{19}$ BOA. DH.ŞFR, 41/235, 12 Mayıs 1914 (29 Nisan 1330).

${ }^{20}$ BOA. DH.ŞFR, 41/195, 8 Haziran 1914 (26 Mayıs 1330).

${ }^{21}$ Papadopoulus, age, s.13-21.
} 
Görüldüğ̈̈ üzere Yunanlıların iddiaları Ayvalık’taki yerel mülki ve askeri idarecilere odaklanmaktaydı. Ayvalık olaylarını bu şekilde değerlendirenler sadece Yunanlılar değildi; Avrupalı devletler de olayların İttihat ve Terakki hükümeti tarafından organize edildiğini düşünüyorlardı. ${ }^{22}$ Buna karşın Karesi Mutasarrıfı Reşit Bey ise suçlamaları kabul etmiyor; Rumların, Ayvalık ile Kuşadası Metropolitlerinin teşvikleri ile kendi istekleriyle göç ettiklerini; şehirde asayişin yerinde olduğunu, herkesin işinde gücünde olduğunu iddia ediyordu. Reşit Bey göndermiş olduğu yazılarda bazen Ayvalık'ta Rumlara karşı saldırı hadiselerini kabul ediyor fakat bu saldırıların Müslüman ya da Rum oldukları tam olarak tespit edilemeyen kişiler tarafından yapıldığını belirtiyordu. ${ }^{23}$

Aslında daha sonra Birinci Dünya Savaşı sırasında Diyarbakır Valiliği de yapacak olan ve Ermeni tehciri nedeniyle ismi herkes tarafından bilinecek olan Mutasarrıf Dr. Reşit Beyin Yunan sefaretinin iddialarına karşı vermiş olduğu cevaplar gerçeği yansıtmıyordu. Çünkü burada gerçekleştirilen tehciri bizzat kendisi yönetiyordu. Bunu da hatıratında açıkça ifade edecekti. Reşit Beyin hatıratında geçen şu ifadeleri onun Rumların göç ettirilmesindeki rolünü açıkça ortaya koymaktadır:

[Diyarbakır'a bir sene evvel gelmiş olsaydım memlekette su-i istimalat ve su-i ahvalin hiç biri vaki olmazdı. (kısaltma AE)]. Buna en klymetli delil Karesi'de bulunduğum zaman vukua gelen ve Yunanistan' 'n Müslümanlara tatbik etdiği zulüm ve itisafata mukabale-bi'l-misl olarak Rumların tehciridir. İmir Vilayetinde bir çok su-i istimaller vaki iken Karesi Livasında bir Rum'un bile burnu kanamamış, emval-i metrukeden bir habbe zayi olmamışdl. Çünkü hemen bir senedir memlekette bulunuyordum. Iktidar ve istikametlerinden emin olmadığım memurları tebdil etdirmiş ve rüfeka-yı mesaimin ahval-i hususiye ve resmiyelerini ögrenmiş ve memleketin eşraf ve ahalisini tanımış idim. Bu sayede Rumlar'ın tehciri birkaç gün zarfında ve intizam-ı tammla ikmal edilmiş ve hiç uygunsuzluk ve şikayet görülmemişti. ${ }^{24}$

Karesi Mutasarrıfi Reşit Beyin kendi ifadeleri de ortaya koymaktadır ki, Ayvalık'ta uygulanan tehcirde bizzat kendisi başrolü oynamaktaydı. Mutasarrıf bir yandan Rumları göç ettiriyor diğer yandan da boşalan yerleri Müslüman muhacirlerle doldurmaya gayret ediyordu. ${ }^{25}$

Ayvalık, meydana gelen bu olaylarla birlikte Batı Anadolu'nun en karışık ve en hassas yeri haline gelmişti. Meydana gelen olaylar Yunan ve Avrupa kamuoyunu ayağa kaldırmıştı. ${ }^{26}$ Yunan hükümeti, Ayvalık olaylarını Anadolu'da yaşanan Rum göçünün son noktası olarak değerlendiriyordu. İki devlet arasında ilişkilerin kopma noktasına gelmesiyle yeni bir Osmanlı Yunan Savaşının çıkma ihtimali iyice belirginleşmişti. ${ }^{27} 12$ Haziranda Yunan Meclisinde ateşli bir konuşma yapan Başbakan Venizelos, Rumların göçü durdurulmadığı takdirde Osmanlı Devletine savaş açacağını söylemişti. ${ }^{28}$ Yunan hükümeti aynı gün Osmanlı devletine şu notayı vermişti. ${ }^{29}$

Hükümetimin emri üzerine sırf Rumlarla meskun Ayvalık kasabasının, müsellah çeteler tarafindan, tecavüze uğramak tehlikesine maruz bulunduğunu zatı Fehimanelerine bildirmiştim.

Sonradan aldı̆̆ım ve zatı Fehimanelerine de okuduğum bir telgraf üzerine de mezkur şehre

\footnotetext{
${ }^{22}$ Bilal Şimşir, Ege Sorunu Belgeler II (1913-1914), TTK Yay., Ankara 1989, s.535-536; BOA. HR.SYS, 1961/20, 31 Ağustos 1914 (18 Ağustos 1330).

${ }^{23}$ BOA.HR. SYS, 2034/5, 10 Haziran 1914 (28 Mayis 1330).

${ }^{24}$ Nejdet Bilgi, Dr. Mehmed Reşid Şahingiray'ın Hayatı ve Hâtıralart-İttihad ve Terakki Dönemi ve Ermeni Meselesi, Akademi Kitabevi, İzmir 1997, s.112-113.

${ }^{25}$ BOA. DH.ŞFR, 429/74, 8 Haziran 1914 (26 Mayss 1330).

${ }^{26}$ BOA. DH.SFR, 49/2, 14 Ocak 1915 (1 Kanunu Sani 1330).

${ }^{27}$ Şimșir, age, s.509, 519.

28 "Atina Ajansindan", İkdam, 14 Haziran 1914 (1 Haziran 1330).

${ }^{29}$ Galip Kemali Söylemezoğlu, Hatıraları Atina Sefareti (1913-1916), Canlı Tarihler, Türkiye Yayınları, İstanbul 1946, s.120.
} 
yapllacak bir tecavüzün, hasll eyleyeceği teessür sevkiye, iki memleket arasındaki münasebetleri nazik bir noktaya vardıracağını, Hüküme-ti Seniyeye bildirmekliğim hakkında Hükümeti Kıraliyeden talimat aldığımı beyan eylemiş̧tim. Feyizli bir kasaba olup, sükunet içinde yaşayan, sirf Rum unsuriyle meskun Ayvalık şehri, müsellah çeteler tarafindan ika edilmekte olup, Osmanlı memurlarının men'ine çalışmadıkları tecavüzlere maruz kalmakta devam etmektedir. Öbür taraftan da, her şeyleri alınmış, bucaklarindan kovulmuş, sefil ve sergerdan, 30.000 Rum, Edremit Körfezi sahillerine iltica ederek, kendilerini Yunanistan'a nakledecek gemiler gönderilmesini dilemektedir. Bunların meskenleri cebren işgal edilmiş ve bütün iaşe maddeleri, yerlerini alan Müslüman ahaliye dağıtılmış olmakla, bu zavallılar açlıktan ölme tehlikesine maruzdurlar. Bunların arasında karmakarlşı halde kadınlar, hastalar, çocuklar, ihtiyarlar vardır. Bir çoğu Hükümeti Kıraliyenin kendilerine temin etmeye çalıştı̆̆ ilticagâhlarına varmadan aldıklart yaralar tesiriyle öleceklerdir.

Trakya'da tatbik edilmiş bulunan taaddiyattan sonra, Küçükasya'da da başlamış bulunan bu hareket, Yunan efkar-ı umumiyesini heyecana getirmiş ve Hükümet-i Kıraliyeden -hiçbir sebebe müstenit olmadan adeta bir imha siyasetine kurban gitmekte olan- bu onbinlerce Rumun himayesi için lazım gelen tedbirlerin alınmasını istemeğe sevk etmiş̧tir.

"Hükümetimden aldığım emre imtisalen, bunu, nezdi Fehimanelerinde en şiddetli bir surette protesto eder ve bu ahvale süratle bir son verilmez ve bu derece felaketlere uğratılmıs bulunan Rumlartn hemen yerlerine dönerek mal ve mülklerine derhal sahip olmalart temin edilmezse, Hükümet-i Kıraliyenin bunlardan doğacak neticelerin mesuliyetini kabul etmeyeceğini arz etmekle şerefyap olmaktaydım.

Yüksek hürmetlerimin tarafı Fehimanelerinden lütfen kabul buyurulmasını dilerim.

\section{Haziran 1914 Panas}

Oldukça sert bir üslupla kaleme alındığ 1 ifade edilen bu savaş notasında; ${ }^{30}$ Ayvalık'ın

Volume 12 etrafının çeteler tarafından sarılmasından, Rumların zorla göç ettirilmesinden, mallarının ve evlerinin ellerinden alınmasından şikâyet ediliyor; Rumların bu durumuna bir an önce son verilmez, evlerine dönmelerine, mallarına sahip olmalarına izin verilmezse Yunan hükümetinin bunlardan doğacak neticenin mesuliyetini kabul etmeyeceği ifade ediliyordu. ${ }^{31} \mathrm{Bu}$ notayla birlikte yeni bir Osmanl1-Yunan savaşına bir adım daha yaklaşılmış olunuyordu. ${ }^{32}$

İttihat ve Terakki hükümeti Avrupa'dan ve Yunanistan'dan gelen bask1lar üzerine yeni bir savaşı göze alamadığ 1 için, Rumları göç ettirme politikasından geri adım atmak zorunda kalmıştı. Sadrazam Said Halim Paşa Dahiliye Nazırı Talat Paşayı, Yunan hükümetinin savaş notas1 vermesinden önce, Rum göçünü durdurmak üzere 8 Haziranda Bat1 Anadolu'ya göndermişti. Göç hareketliliğinin yaşandığı yerleri incelemelerde bulunacak olan Talat Paşa göçün sona erdirilmesi için gerekli tedbirler alacaktı. ${ }^{33}$

Talat Paşanın Karesi Livasına gelmesinden sonra göndermiş olduğu telgraflar Ayvalık ve çevresinde yaşanan göç hareketliliğini ortaya koymaktayd1. Onun verdiği bilgilere göre Edremit ve Burhaniye'den 16 binin üzerinde Rum göç etmişti. Özellikle muhacir iskan olunan köylerde yaşayan Rumların hepsi göç etmişlerdi. ${ }^{34}$ Göç eden Rumlara ve mallarına karşı saldırı olayları da olmuştu. Ayrıca iki kadın kaçırılmış ve birisine tecavüz edilmişti. ${ }^{35}$ Yapılan incelemelerde olaylara karıştığı tespit edilen Burhaniye Belediye Başkanı azledilerek

\footnotetext{
${ }^{30}$ Bilal Şimşir, age, s. 525; "Yunanın Notası”, İkdam, 14 Haziran 1914 (1 Haziran 1330).

${ }^{31}$ BOA. HR.SYS, 2033/1, 12 Haziran 1914 (30 Mayıs 1330).

32 "Rumca Gazetelerden”, İkdam 18 Haziran 1914 (5 Haziran 1330); Şimşir, age, s.528.

33 "Talat Beyin Beyanatı", İkdam, 11 Haziran 1914 (29 Mayıs 1330).

${ }^{34}$ BOA. DH.SFR, 41/195, 8 Haziran 1914 (26 Mayis 1330).

${ }^{35}$ BOA. HR.SYS, 2034/5, 12 Haziran 1914 (30 Mayls 1330).
} 
tutuklanmış, Balya Jandarma Bölük Kumandanı ile İvrindi Takım Kumandanı İsmail Hakkı ve Rıfat Efendiler azledilmişlerdi. ${ }^{36}$

Talat Paşa Edremit'teki incelemelerinden sonra Yunanistan'ın Osmanlı Devletine savaş notası verdiği gün Ayvalık'a gelmişti. ${ }^{37}$ Ayvalık'tan gönderdiği telgrafta; kendisinden önce Ayvalık'a bağlı Küçükköy'den 800 hane göç etmek üzere şehre geldiğini; Ayvalık halkının da göç etmek üzere 4-5 vapur kiraladığını ve bu kişilerin evlerine iade edildiğini bildiriyordu. Dahiliye Nazırı buradan göndermiş olduğu telgraflarda özellikle Yunanistan'ın savaş notasında bahsettiği saldırı ve baskı iddialarını yalanlamaya gayret ediyordu. 13 Haziran 1914'te gönderdiği telgrafında Ayvalık'taki Yunan, Fransız, İtalyan Konsolosları ve Metropolitiyle görüştüğünü, bu kişilerin kendisine Ayvalık'ta o güne kadar kimsenin burnunun kanamadığını, kimsenin malına saldırı olmadığını, zabitlerin kumandasında çetelerin teşkil edildiği şeklindeki şikayetlerin kaynağını sorduğunda da görüştüğü kişilerin bunları halktan işittiklerini ve ne derece doğru olduğunu bilmedikleri cevabını aldığını bildirmişti. ${ }^{38}$

Aynı şekilde Karesi Mutasarrıfı Reşid Bey de 14 Haziran 1914'te Dâhiliye Nezaretine gönderdiği telgrafında Ayvalık'ta tebdil-i kıyafet etmiş zabit ve başıbozukların bir araya gelerek şehre hücum edecekleri ve şehre erzak girişinin yasaklandığı şeklindeki iddiaların gerçek olmadığını ifade ediyordu. ${ }^{39}$ Belirtmek gerekir ki hem Talat Paşa'nın hem de Karesi Mutasarrıfı Reşit Beyin Ayvalık'ta asayişin yerinde olduğu ve Rumlara herhangi bir saldırının olmadığına yönelik telgrafları Yunan ve Avrupa kamuoylarını sakinleştirmeye yönelikti. Buna rağmen Talat Paşa bazen gönderdiği telgraflarda Ayvalık ve Yunda ahalisi Rumlarının korku içinde kaldıklarını ve korkudan tarlalarına dahi gidemediklerini yazıyordu. ${ }^{40}$ Ancak bu korkunun nasıl oluştuğunu açıklamıyordu.

Dahiliye Nazırı Talat Paşa Ayvalık'a geldiği günlerde Rumların göç etmeleri engellenmişti. ${ }^{41}$ Ancak Rumlara karşı saldırıları ve göçü tamamen durdurmak mümkün olamıyordu. ${ }^{42}$ Kısa bir zaman sonra yeniden göç hareketliliği yaşanmaya başlanmıştı. ${ }^{43}$ Karesi Mutasarrıflığı Dahiliye Nezaretine gönderdiği 26 Temmuz 1914 tarihli telgrafinda Ayvalık'ın Küçükköy Nahiyesindeki 700 haneden 150'sinin Midilli'ye, geride kalanların hepsinin de Ayvalık merkezine göç ettiklerini bildiriliyordu. ${ }^{44}$

İttihat ve Terakki, 1914 yılının Haziran ayında Yunanistan'ın verdiği savaş notası ve Avrupalı Devletlerden gelen baskılar nedeniyle gayrı resmi bir şekilde uyguladığı tehciri durdurmak zorunda kalmıştı. Batı Anadolu'da çok kısa bir zaman zarfında uygulanan tehcirde nüfusunun tamamına yakını göç etmiş olan Çeşme, Kuşadası gibi yerlerdeki sonucun bir

\footnotetext{
${ }^{36}$ BOA. HR.SYS, 2034/5, 10 Haziran 1914 (28 Mayis 1330).

${ }^{37}$ BOA. DH.ŞFR, 430/10, 12 Haziran 1914 (30 Mayıs 1330).

${ }^{38}$ BOA. DHŞFR, 430/23, 13 Haziran 1914 (31 Mayıs 1330).

${ }^{39}$ BOA. DH.ŞFR, 430/29, 14 Haziran 1914 (1 Haziran 1330).

40 BOA. DHŞFR, 430/23, 13 Haziran 1914 (31 Mayıs 1330); BOA.HR.SYS, 2034/5, 13 Haziran 1914 (31 Mayıs 1330); BOA. HR.SYS, 2034/5, 14 Haziran 1914 (1 Haziran 1330)

${ }^{41}$ BOA. DH.ŞFR, 431/14, 19 Haziran 1914 (6 Haziran 1330); BOA. Dahiliye Nezareti Kalemi Mahsus (BOA. DH.KMS), 19/68, 19 Haziran 1914 (6 Haziran 1330).

${ }^{42}$ BOA. HR.SYS, 2034/5, 15 Haziran 1914 (2 Haziran 1330); BOA. HR.SYS, 2034/5, 14 Haziran 1914 (1 Haziran 1330); BOA. HR.SYS, 2034/5, 24 Haziran 19141 (1 Haziran 1330); BOA. DH.KMS, 19/67, 16 Haziran 1914 (3 Haziran 1330); BOA. DH.KMS, 19/67, 17 Haziran 1914 (4 Haziran 1330); BOA. DH.EUM.EMN, 8/10, 28 Haziran 1914 (15 Haziran 1330).

${ }^{43}$ BOA. DH.ŞFR, 44/46, 18 Ağustos 1914 (5 Ağustos 1330); BOA. DH.ŞFR, 44/135, 30 Ağustos 1914 (17 Ağustos 1330); BOA.DH.ŞFR, 433/48, 10 Temmuz 1914 (27 Haziran 1330).

${ }^{44}$ BOA. DH.ŞFR, 434/76, 26 Temmuz 1914 (13 Temmuz 1330).
} 
benzeri Ayvalık'ta elde edilememişti. Burada yaşayan 31.440 Rumdan ${ }^{45}$ olaylar sırasında 9 bin civarında bir nüfus göç etmişti. ${ }^{46}$ Bundan dolayı Ayvalık Birinci Dünya Savaşı sırasında da hükümet nazarında bir sorun olmaya devam edecekti.

\section{3-I.Dünya Savașı Sırasında Ayvalık Rumlarının Tehcir Edilmesi}

Ayvalık, Birinci Dünya Savaşında da Balkan Savaşında olduğu gibi güvenlik sorunlarının yaşandığı bir yer haline gelmişti. İtilaf Devletleri Osmanlı Devletinin savaşa dahil olmasından hemen sonra onu savaş dışı bırakmak için Çanakkale'ye saldırma kararı almışlardı. Bu amaçla Ege Denizinde Yunanistan'ın elinde bulunan Midilli, Sakı, Sisam gibi Batı Anadolu sahillerinin hemen yanı başındaki adaları askeri üs haline getirmişlerdi. Adalara konuşlanan İtilaf Devletleri Batı Anadolu sahillerini ablukaya almış, yoğun bir şekilde sahillere saldırıyorlardı ${ }^{47}$ İngiliz ve Fransız savaş gemilerinin çok yoğun bir şekilde saldırdığ yerlerden bir tanesi de Ayvalık'tı. ${ }^{48}$ Midilli'den gelen savaş gemileri, savaş uçakları ve denizaltılar askeri mevzileri, yerleşim merkezlerini, fabrikaları, karakolları bombalıyorlardı. ${ }^{49}$ Yaşanan bu saldırılarla birlikte İtilaf Devletlerinin Ayvalık'a asker çıkaracaklarına dair istihbaratlar da elde ediliyordu. ${ }^{50}$

Adalara yerleşen İngiliz ve Fransızlar buralarda yaşayan Rum göçmenlerinden çeteler kuruyorlar ve bu çeteleri Anadolu sahillerine saldırtıyorlard1. ${ }^{51}$ Anadolu sahillerine saldıran bu eşkıyalar Osmanlı askerlerine ateş açıyorlar köyleri basıyorlar, hırsızlık ve yağma yapıp Müslüman ahaliyi öldürüyorlar; çetelere katılmak üzere askerden kaçanları kayık ve sandallarla adalara kaçırıyorlar; Anadolu sahillerindeki Rumları silahlandırıyorlardı. ${ }^{52}$ Bunlardan başka Ayvalık ve çevresindeki Rumları isyana teşvik ediyorlardı. Göndermiş oldukları mektuplarda Ayvalık'ın yakında Yunanistan olacağını, ${ }^{53}$ İngiliz ve Fransız donanmalarının Ayvalık ile Edremit ve Burhaniye sahillerine asker çıkaracağını haber vererek hazırlıklı olmalarını

Volume 12 Issue 3 June 2020 istiyorlardı. ${ }^{54}$ Ayvalıklı Rumlar da İtilaf Devletlerine ve onların kurmuş oldukları çetelere

${ }^{45}$ Kemal H. Karpat, Osmanlı Nüfusu (1830-1914) Demografik ve Sosyal Özellikler, Tarih Vakfı Yurt yay. İstanbul 2003, s.224.

${ }^{46}$ BOA. Dahiliye Nezareti Emniyeti Umumiye Müdüriyeti 3. Şube (BOA. DH.EUM.3.ŞB), 8/1, 12 Ağustos 1915 (30 Temmuz 1331).

${ }^{47}$ Önder Duman, Emperyal Bir Araç Olarak Rum Pontus Sorunu (1908-1918), Berikan Yayınevi, Ankara 2010, s.47-57.

${ }^{48}$ BOA. DH.EUM.3. SB, 2/45, 1 Kasım 1914 (19 Teşrin-i Evvel 1330); BOA. DH.EUM.3. SB, 2/52, 4 Kasım 1914 (22 Teşrin-i Evvel 1330); BOA. DH.EUM.3. ŞB, 2/53, 4 Kasım 1914 (22 Teşrin-i Evvel 1330); BOA. DH.EUM.3. SSB, 2/60, 10 Kasım 1914 (28 Teşrin-i Evvel 1330); BOA. DH.EUM.3. ŞB, 3/31, 6 Ocak 1915 (24 Kanun-u Evvel $1330)$.

${ }^{49}$ BOA. DH.EUM.3.ŞB, 7/65, 4 Temmuz 1915 (21 Haziran 1331); BOA. DH.EUM.3.ŞB, 7/65, 7 Temmuz 1915 (24 Haziran 1331); BOA. DH. EUM.3.ŞB, 10/22, 2 Aralık 1915 (19 Teşrin-i Sani 1331); BOA. DH.EUM.3.ŞB, 11/46, 9 Şubat 1916 (27 Kanun-1 Sani 1331).

${ }^{50}$ Liman Von Sanders, Türkiye'de Beș Sene, Yeditepe Yay., İstanbul 2006, s. 109; BOA. DH.SFR, 7/50, 31 Temmuz 1915 (18 Temmuz 1331).

${ }^{51}$ BOA. DH.EUM.3.ŞB, 1/60, 19 Eylül 1914 (6 Eylül 1330); BOA. DH.EUM.3.ŞB 1/61, 20 Eylül 1914 (7 Eylül 1330); BOA. DH.EUM.3.ŞB, 7/65, 3 Temmuz 1915 (20 Haziran 1331); BOA. DH.EUM.3.ŞB, 5/21, 1 Mayıs 1915 (1 Mayıs 1331); BOA. DH.EUM.3.ŞB, 2/42, 31 Ekim 1914 (18 Teşrinievvel 1330); BOA. DH.EUM.3.ŞB, 12/13, 29 Şubat 1916 (16 Şubat 1331); BOA. Dahiliye Nezareti 5. Şube (BOA. DH.EUM.5.ŞB, 2/34, 27 Eylül 1914 (14 Eylül 1330); BOA. DH.ŞFR,451/137, 5 Aralık 1914 (22 Teşrini Sani 1330); BOA. DH.ŞFR, 492/42, 5 Ekim 1915 (22 Eylül 1331);).

${ }^{52}$ BOA. DH.ŞFR, 55/81, 18 Ağustos 1915 (5 Ağustos 1331); BOA. DH.EUM.3.ŞB, 12/13, 29 Şubat 1916 (16 Şubat 1331).

${ }^{53}$ BOA. DH.EUM.3.ŞB, 3/6, 29 Kasım 1914 (16 Teşrin-i Sani 1330).

${ }^{54}$ BOA. DH.EUM.3.SB, 7/50, 31 Temmuz 1915 (18 Temmuz 1331). 
destek oluyorlardı. ${ }^{55}$ Midilli adasına yiyecek kaçırıyorlardı. ${ }^{56}$ Askerden kaçmalar artmıştı. ${ }^{57}$ Asker kaçakları gizlice Midilli adasına gidip oradaki çetelere katılıyorlardı. Ayrıca İtilaf Devletleri için casusluk yapıyorlard1. ${ }^{58}$

Ayvalıklı Rumlar ,yürüttükleri zararlı faaliyetlerle, Balkan Savaşında olduğu gibi bu savaşta da Osmanlı Devletini cephe gerisinde zaafa uğratmaya çalışıyorlardı. İttihat ve Terakki hükümeti almış olduğu askeri tedbirlerle Rumların zararlı faaliyetlerini önlemeye çalışıyordu. Alınan güvenlik önlemleri kapsamında sahile giriş ve çıkışlar sıkı kontrol altında tutuluyordu. Ayrıca asker kaçaklarını ve eşkıyaları yakalamak için çok sık aramalar yapılıyordu. Zararlı görülen kişiler Karesi merkezine uzaklaştırılıyordu. ${ }^{59} \mathrm{Bu}$ önlemlerle 1915'in ortalarına kadar Rumlar kontrol altında tutulmaya çalışılacaktı.

Ancak belirtmek gerekir ki Rumların itilaf Devletleriyle işbirliği yapmalarını ve isyan etmelerini önlemek adına alına tedbirler bir çok şikayete ve bir çok uygunsuz davranış ve olayın meydana gelmesine de neden olmaktaydı. Mülkiye müfettişlerinin raporlarına ve Karesi Mutasarrıflı̆̆ının telgraflarına yansıyan uygulamalar şu şekildeydi: Bazı sarhoş jandarmalar Rumları rahatsız ediyordu. Askerler mezar taşlarını tahrip ediyorlardı. Rumlar aleyhine meydana gelen adli olaylar kapatılıyordu. İdareciler özellikle askerden kurtarmak için Rumlardan rüşvet alıyorlardı. Rumların Ayazment'teki zeytin bahçelerine gitmeleri engelleniyor, bu da onların ekonomik sıkıntı çekmelerine ve bahçelerinin bakımsızlıktan zarar görmesine neden oluyordu. Rumların Ayazment'teki arazileri muhacirlere dağıtılıyordu. Hatta bu araziler bedelsiz bir şekilde istimlak edilmeye çalışılıyordu. Ayazment civarında Rumlara karşı katl olayları yaşanıyordu. Engellemeler Rumların vergilerini ödeyemeyecek derecede ekonomik durumlarının bozulmasına neden oluyordu. Laz muhacirler Rumlara saldırıyorlardı. Mektebe asker yerleştirilmişti ve Rumlara mekteplerini artık idare edemeyecekleri tebliğ edilmişti. İnsanların ekonomik durumları kötü olmasına rağmen yol vergisi yüksekti. Vergi toplayan tahsildarlar ahaliye kötü davranıyorlardı. ${ }^{60}$ Hane ve mağazalar basılarak Tekalifi Harbiye kapsamında olmayan mallar zorla alınıyordu. Tekalifi Harbiye için sürekli aramalar yapılıyordu. ${ }^{61}$ Ayrıca asker kaçakları için yapılan aramalar çok uzun sürüyor; şehrin dışarıyla olan bağlantısı kesiliyordu. Böyle zamanlarda Rumlara saldırmaları yönünde Müslüman ahaliye dağıtıldığı iddia olunan mühürlü zarflar, Rumların korkmalarına neden oluyordu. Çeşitli zamanlarda idareciler tarafından şehre erzak girişi yasaklanıyordu. Bu yasaklama zamanlarında insanlar cok ciddi açlık yaşıyorlard1. Hatta açlıktan ölenler oluyordu. Katl ve ortadan kaybolma vakaları yaşanıyordu. ${ }^{62}$

\footnotetext{
${ }^{55}$ Mustafa Sarı, "Birinci Dünya Savaşı'nda Batı Anadolu'da Rumların Casusluk ve Çetecelik Faaliyetleri”, History Studies, Vol. 7, Issue 1, March 2015, s.181.

${ }^{56}$ BOA. DH.ŞFR, 439/83, 03 Eylül 1914 (21 Ağustos 1330).

${ }^{57}$ BOA. HR.SYS, 1961/20, 26 Eylül 1914 (13 Eylül 1330); BOA. DH.ŞFR, 455/131, 28 Aralık 1914 (15 Kanunu Evvel 1330); BOA. DH.ŞFR, 455/17, 12 Ocak 1915 (10 Kanunu Evvel 1330).

${ }^{58}$ BOA. DH.ŞFR, 487/4, 20 Eylül 1331 (3 Ekim 1915); BOA. DH.ŞFR, 451/30, 16 Teşrini Sani 1330 (29 Ekim 1914); BOA. DH.ŞFR , 451/130, 04 Aralık 1914 (21 Teşrini Sani 1330); BOA. DH.ŞFR, 439/83, 03 Eylül 1914 (21 Ağustos 1330); BOA. Bab-ı Ali Evrak Odası (BOA. BEO), 4354/326487, 8 Mayıs 1915 (25 Nisan 1331).

${ }_{59}$ BOA. DH.SFR, 437/90, 18 Ağustos 1914 (5 Ağustos 1330).

${ }^{60}$ BOA. DH.ID, 222/22, 1 Mart 1915 (16 Şubat 1330); BOA. DH.ID, 222/22, 8 Mart 1915 (23 Şubat 1330); BOA. DH.SFR, 455/65, 25 Aralık 1914 (12 Kanunu Evvel 1330);

BOA. DH.ŞFR, 54/A-241, 2 Ağustos 1915 (20 Temuz 1331); BOA. DH.ŞFR, 55/90, 18 Ağustos 1915 (5 Ağustos 1331); BOA. DH.ŞFR, 464/45, 8 Mart 1915 (23 Şubat 1330); BOA. DH.ŞFR, 477/100, 28 Haziran 1915 (15 Haziran 1331); BOA. DH.ŞFR, 458/57, 18 Ocak 1915 (5 Kanunu Sani 1330).

${ }^{61}$ BOA. DH.EUM.3.ŞB, 1/31, 24 Ağustos 1914 (11 Ağustos 1330); BOA. DH.EUM.3.ŞB 1/31, 18 Ağustos 1914 (5 Ağustos 1330); BOA. DH.SFR, 44/46, 18 Ağustos 1914 (5 Ağustos 1330).

${ }^{62}$ BOA. DH.ŞFR 458/35, 17 Ocak 1915 (4 Kanunu Sani 1330); BOA. DH.ŞFR 50/164, 4 Mart 1915 (19 Şubat 1330); BOA. DH.ŞFR, 464/45, 8 Mart 1915 (23 Şubat 1330); BOA. DH.ŞFR, 49/2, 14 Ocak 1915 (1 Kanunu Sani 1330);
} 
Ayvalık'ta yaşanan bu hadiseler, daha önce olduğu gibi yine Yunan kamuoyunda tepkilere neden olmuştu. Ülkesinde tekrar iktidara gelerek Yunanistan'1 İtilaf Devletlerinin safında savaşa sokmak isteyen Venizelos, Anadolu'da Rumlarla alakalı meydana gelen hadiseleri kullanarak Yunan kamuoyunu harekete geçirmeye çalışıyordu. Yunanistan'ın tarafsızlığının devam etmesini isteyen Osmanlı Devletinin müttefiki Almanya da İttihat ve Terakki hükümetinden şikâyetlere son verilmesini istemişti. Böylece İttihat ve Terakki 1915 yılının Temmuz ayından itibaren siyaseten Rumlara karşı daha yumuşak bir politika uygulama kararı almıştı. Dâhiliye Nazarı Talat Paşa 16 Temmuz 1915'te vilayet ve mutasarrıflıklara Rumlara karşı şikayete neden olabilecek olaylara meydan verilmemesi talimatını göndermişti. ${ }^{63} \mathrm{Bu}$ yeni durum Ayvalık’ı da ilgilendiriyordu. Çünkü Almanya özellikle Ayvalık ile alakalı şikâyetlere son verilmesini istemişti. ${ }^{64}$

Aslında Talat Paşa'nın Rumlara yumuşak davranılması talimatını gönderdiği 1915'in Temmuz ayında askeriye, Ayvalık'a bağlı Yunda adasındaki Rumları tehcir etme kararı almıştı. Askeriyenin tehcir kararı almasının sebebi İtilaf Devletlerinin Ayvalık ve Edremit sahiline asker çıkaracağı istihbaratıydı. Elde edilen bilgilere göre, Midilli'de yayımlanan Salbis gazetesi 3 Ağustosta yani Yunan Meclisinin açılış gününde Midilli adasında bulunan 13 İngiliz nakliye gemisinin Ayvalık ve Edremit sahiline asker çıkaracağını yazmıştı. Bundan başka yetkililer, ele geçirilen mektuplarda 3 Ağustosu işaret eden ifadeleri, İtilaf Devletlerinin sahile saldırmaları şeklinde yorumlamışlardı. ${ }^{65}$

Askeriyenin aldığı tehcir kararından ne Karesi Mutasarrıfının ne de Dahiliye Nezaretinin haberi vardı. Askeriyenin Yunda adasında yaşayan Rumları tehcir etme kararı Talat Paşa'nın 22 Temmuz 1915'te Karesi Mutasarrıfını Ayvalık'ta araştırma yapmak üzere görevlendirmesiyle ortaya çıkmıştı. ${ }^{66}$ Mutasarrıf, İzmir'deki 4. Kolordu Kumandanlığının Yunda Rumlarıve Ayvalık merkezinden Metropolit ile birlikte 250 kişiyi tehcir etmeyi kararlaştırdığını öğrenince oldukça şaşırmıştı. Mutasarrıfa göre, burada uygulanacak tehcirin, Rumlara yumuşak davranma siyasetiyle bağdaştırması mümkün değildi. Ayrıca Yunda adasını Marmara adası gibi tahliye etmek mümkün değildi. Tahliye başladığında düşman gemileri gelerek Rumları alıp götürebilirlerdi; bunun yaşanması hükümeti zor duruma düşürecekti.

Mutasarrıf, Dahiliye Nezaretine gönderdiği yazısında, tehcirin ertelenmesini ve bundan sonra doğrudan savaş alanı olmayan yerlerde liva ile görüşmeden tehcir kararı alınmamasının ilgili kişilere tebliğ edilmesini istemişti. Dahiliye Nazırı Talat Paşa da 29 Temmuz 1915'te Harbiye ve Hariciye Nezareti'ne gönderdiği yazısında Ayvalık'ta uygulanacak bu tehcirin Dünya Savaşında henüz daha tarafsızlığını koruyan Yunanistan'da büyük bir tepki doğuracağını; tehcirin Rumlara uygulanan yumuşak siyasetle bağdaşmadığını belirterek şimdilik uygulanmamasını istemişti. ${ }^{67}$

Askeriye o zaman için Yunda Rumlarını tehcir etmekten vazgeçmişti. ${ }^{68}$ Fakat ordunun tehcir kararının bu şekilde ortaya çıkması adada yaşayan Rumların 1915'in Aralık ayında isyan

BOA. DH.ŞFR 49/29, 16 Ocak 1915 (3 Kanunu Sani 1330); BOA. DH.ŞFR, 484/31, 16 Ağustos 1915 (3 Ağustos 1330); BOA.DH.SFR, 540/46. 14 Aralık 1916 (1 Kanunu Evvel 1332); BOA. DH.SSFR 49/29, 16 Ocak 1915 (3 Kanunu Sani 1330); BOA. DH.ŞFR, 484/31, 16 Ağustos 1915 (3 Ağustos 1330); BOA. DH.ŞFR, 49/2, 14 Ocak 1915 (1 Kanunu Sani 1330); BOA. Hariciye Nezareti Hukuk Kısmı (BOA. HR.H), 694/17, 8 Mart 1915 (23 Şubat 1330).

${ }^{63}$ BOA. DH.ŞFR, 54/A-109, 16 Temmuz 1915 (3 Temmuz 1331).

${ }^{64}$ BOA. DH.ŞFR, 483/24, 8 Ağustos 1915 (26 Temmuz 1331).

${ }^{65}$ BOA. DH.ŞFR, 481/127, 31 Temmuz 1915 (18 Temmuz 1331).

${ }^{66}$ BOA. DH.ŞFR, 54A/68, 22 Temmuz 1915 (9 Temmuz 1331).

${ }^{67}$ BOA. DH.ŞFR, 481/26, 25 Temmuz 1915 (12 Temmuz 1331); BOA. BEO 4366/327427, 25 Temmuz 1915 (12 Temmuz 1331).

${ }^{68}$ BOA. BEO, 4366/327427, 29 Temmuz 1915 (16 Temmuz 1331). 
etmesine neden olmuştu. ${ }^{69}$ Olay şu şekilde meydana gelmişti: 1 Aralıkta Yunda adasının kuzeyinde yer alan ve adaya çok yakın olan Pateriça adasında devriye gezen 9 kişilik Osmanlı müfrezesi eşkıyaların ve İtilaf Devletlerinin gambotunun saldırısına uğrayınca ${ }^{70}$ Osmanlı askerleri adaya gelmişti. Askerlerin adaya gelmesiyle tehcirin başladığını zanneden Rumlar bir kişiyi Selanik’teki İngiliz Amiraline göndererek kendilerini kurtarmasını ve gelip adayı işgal etmesini istemişlerdi. 5 Aralıkta Yunda adasında Osmanlı askerleri ile İngiliz askerleri ve Rum eşkiyası arasında büyük bir çatışma çıkmıştı. Osmanlı askerleri geri çekilmek zorunda kalınca ada halkı silaha sarılmış, resmi binaları ele geçirmişti. Osmanlı askerleri Ayvalık merkezinden takviye güçler geldikten sonra Yunda adasına tekrar hakim olabilmişti. Bunun üzerine İngiliz savaş gemileri 305 hane Rum'u Midilli adasına götürmüştü. Geride kalan 485 hanede ki 1350 kişinin tamam1 ${ }^{71}$ ise Ayvalık'a nakledilmişti. ${ }^{72}$

Dünya Savaşı sırasında İttihat ve Terakki hükümeti Rumlara uygulayacağı politikalarını Yunanistan'daki gelişmelere göre ayarlamaktaydı. Hükümet Yunanistan'ın tarafsızlığı devam ettiği sürece Rumlara karşı Yunan kamuoyunda tepkilere neden olacak adımlar atmak istemiyordu. Talat Paşa askeriyenin istediği Yunda tehcirine bu kaygı ile karşı çıkmıştı. Ancak Yunanistan 1916 yılından itibaren savaşa dahil olmaya başlamıştı. Bu durumu yakından takip eden İttihat ve Terakki ülke genelinde uygulayacağı Rum tehcirinin hazırlıklarına 1916 yılının Eylül ayından itibaren başlamıștı. Dahiliye Nazırı Talat Paşa 4 Eylül 1916'da tüm vilayet ve livalara gönderdiği talimatla, Yunan tebalıların ve Rumların sıkı gözetim altına alınmasını ${ }^{73}$ ve sahil kesimlerinde yaşayan Rumların dahile alınması için hazırlıklara başlanmasını istemişti. ${ }^{74}$ $\mathrm{Bu}$ talimattan sonra Ayvalık'ta da tehcir hazırlıkları yapılmaya başlanmış, ${ }^{75}$ Metropolit ile birlikte 300 kişinin Ayvalık'tan İzmir'e sevk edilmesi kararlaştırılmıştı. ${ }^{76}$

Askeriye 1917 yılı Mart ayında Ayvalık'ı tamamen tahliye etme kararı alacaktı. Bunun da sebebi 1916'nın Ekim ayında Çıplak adasına yapılan baskında casuslukla ilgili evrakların ele geçirilmiş olmasıyd.$^{77}$ 5.Ordu Kumandanlığ 1 , ortaya çıkarılan casusluk teşkilatı ve İtilaf Devletlerinin sahile asker çıkaracağı yönündeki istihbaratlara ${ }^{78}$ dayanarak Ayvalık'ın tamamen boşaltılmasına karar vermişti. Askeriye daha önce olduğu gibi Dahiliye Nezaretine haber vermeden tehcir kararı almıştı. ${ }^{79}$ Talat Paşa tehcir kararını öğrendiğinde şehrin tamamen boşaltılmasına karşı çıkmış ve sadece şüpheli ve tehlikeli kişilerin sevkiyle yetinilmesi, kadın çocuk ve tehlikesiz olanlara dokunulmamasını istemişti. ${ }^{80}$

Talat Paşa şehrin tamamen boşaltılmasına karşı çıkmıştı ama yine de biraz kafası karışıktı. 28 Mart tarihli telgrafından, Ayvalık'ın tamamen tahliyesi fikrini doğru bulmadığı anlaşılmaktadır. Ancak bir gün sonra fikrini değiştirmiş, Karesi Mutasarrıflı̆̆ına tahliyeler için hazırlıklar yapılması talimatını göndermişti. Bundan başka, 15 Mayıs’ta Hariciye Nezaretine

${ }^{69}$ BOA. DH.EUM.3.ŞB, 11/11, 13 Aralı 1915 (30 Teşrini Sani 1915).

${ }^{70}$ BOA. HR.SYS, 2102/2, 27 Aralık 19151 (4 Kanunu Evvel 1331).

${ }^{71}$ BOA. HR.SYS, 2102/2, 27 Aralık 1915 (14 Kanunu Evvel 1331); BOA. HR.SYS, 2102/2, 15 Haziran 1916 (2 Haziran 1332); BOA. DH.EUM.3.ŞB, 10/22, 2 Aralık 1915 (19 Teşrini Sani 1331).

${ }^{72}$ BOA. DH.ŞFR, 501/35, 12/13 Aralık 1915 (28/29 Teşrini Sani 1331); BOA. DH.ŞFR, 666/141, 9 Aralık 1915 (26 Teşrini Sani 1331); BOA. DH.EUM.3.ŞB, 14/9, 1 Şubat 1916 (19 Kanunu Sani 1331).

${ }^{73}$ BOA. DH.ŞFR, 67/187, 4 Eylül 1916 (22 Ağustos 1332).

${ }^{74}$ BOA. DH.ŞFR, 67/243, 11 Eylül 1916 (29 Ağustos 1332).

${ }^{75}$ BOA. DH.ŞFR, 531/102, 11 Eylül 1916 (29 Ağustos 1332); BOA. DH.ŞFR, 68/9, 14 Eylül 1916 (1 Eylül 1332).

${ }^{76}$ BOA. DH.ŞFR, 531/102, 30 Eylül 1916 (17 Eylül 1332); BOA. DH.ŞFR, 534/43, 4 Ekim 1916 (21 Eylül 1332); BOA. DH.ŞFR, 534/78, 7 Ekim 1916 (24 Eylül 1332); Persecution of the Greeks in Turkey 1914-1918, s.67.

${ }^{77}$ BOA. DH.ŞFR, 534/43, 4 Ekim 1916 (21 Eylül 1332); BOA. DH.ŞFR, 534/78, 7 Ekim 1916 (24 Eylül 1332).

${ }^{78}$ BOA. DH.ŞFR, 545/27, 8 Şubat 1917 (26 Kanunu Sani 1332).

${ }^{79}$ BOA. DH.ŞFR, 549/34, 24 Mart 1917 (1333); BOA. DH.ŞFR, 549/58, 25 Mart 1917 (1333)

${ }^{80}$ BOA. DH.ŞFR, 74/274, 28 Mart 1917 (1333). 
gönderdiği yazısında, casusluğun önlenemeyeceği kanaatinin oluşmasından dolayı, 5. Ordunun Ayvalık' ın tahliyesine karar verdiğini belirtmişti. ${ }^{81} 4$ Nisanda Karesi Mutasarrıflığına gönderdiği telgrafında ise Ayvalık'ın tahliyesi konusunda gösterilen kararlılığın askeri olmaktan ziyade başka bir fikre dayandığını ifade etmişti. Talat Paşa "başka fikir" derken neyi kastettiğini açıkça ifade etmemiştir. Telgrafın devamında Ayvalık Rumlarının mallarının korunmasının mülki idareye ait olduğunu ifade etmiş ve Mutasarrıftan alınması gereken tedbirler hakkındaki görüş ve önerilerini bildirmesini istemişti. ${ }^{82} \mathrm{Bu}$ ilginç telgraftan sonra 8 Nisanda gönderilen telgrafla; Tahliyeler esbab-ı askeriyeye müsteniddir. Fakat şayiaya meydan verilmemesi lazım gelir talimatını göndermişti. ${ }^{83}$

Karesi Mutasarrıfı da Ayvalık'ın tamamen boşaltılmasına karşı çıkmaktaydı. Mutasarrıfın değerlendirmesine göre; 18-20 bin kişiyi iç kesimlerde yer alan Gönen, Sındırg1, Balya gibi kazalarda iskan etmek, iaşelerini temin etmek mümkün değildi. Buralar Müslüman muhacirler ve Rum mülteciler ile doluydu ve toptan sevk edilirlerse Ayvalıklılar sefil ve perişan olacaklar, aç kalacaklardı. Mutasarrıf, Ayvalıklıların İzmir, Bursa, Manisa, Kütahya, Afyon'a sevklerinin daha uygun olacağını düşünmekteydi. ${ }^{84}$ Mutasarrıf İbrahim Süreyya Bey nakil aracı ve iaşe temini konularında da yaşanacak sıkıntılardan dolayı tahliyelerin sadece muzır ve tehlikeli kişilerle sınırlı tutulmasını, Ayvalıklıların tamamının sevk edilmemesini istemekteydi. ${ }^{85}$

Mutasarrıfın karşı çıkmasına rağmen askeriye Ayvalık'ın tamamen boşaltılmasında 1srarciyd1. 29 Mart 1917'de Karesi Mutasarrıflı̆̆ına gönderilen telgrafla öncelikle askeriyenin gerekli gördügü kişiler daha sonra da ahalinin tamamının sevk edileceği bildirilmişti. Gönderilen talimatlara göre; tehcir edilenlerin nakil, iaşe ve iskanları yerel mülki ve askeri idareciler tarafından temin edilecekti. Sevk ve iskanlar sırasında Rumların Müslüman ahalinin ve memurların hakaret ve saldırılarına uğramalarına meydan verilmeyecekti. Sevk edilirken Rumlara istedikleri eşyalarını almalarına izin verilecekti. Rumların nerelere sevk edilebilecekleri 5. Ordu Kumandanlığ tarafindan tespit edildikten sonra bildirilecekti. Aciz ve muhtaç olanların liva dâhilinde iskânlarına çalışılacaktı. Sevk işlemlerinin düzenli olması için Bursa ve İzmir ile irtibata geçilecekti. Sevk işlemleri ve iaşe sorunu hakkında peyderpey merkeze rapor gönderilecekti. ${ }^{86}$ Bursa ve İzmir vilayetlerine sevk edilenlerin iskânları için oralarda da hazırlıklar yapılacaktı. ${ }^{87}$

Ayvalık tehciri ilk olarak 29 Mart 1917'de 1400 kişilik kafilenin yola çıkarılmasıyla başlamıştı. ${ }^{88}$ Belgelere yansıyan 120 kişilik ikinci kafile 31 Martta Karesi' ye gitmek üzere yola çıkarılmıştı. Kafilelerin konaklama ve iaşe merkezi olarak Karesi Livası tespit edilmişti. ${ }^{89}$ Denizli'ye 5 bin kişi gönderilmesi planlanmıştı. Bu kişiler trenle İzmir üzerinden sevk edileceklerdi. ${ }^{90}$

${ }^{81}$ BOA. BEO, 335292, 15 Mayis 1917 (1333).

${ }^{82}$ BOA. DH.ŞFR, 75/46, 4 Nisan 1917 (1333); BOA. DH.ŞFR, 550/92, 6 Nisan 1917 (1333)

${ }^{83}$ BOA. DH.ŞFR, 75/81, 8 Nisan 1917 (1333).

${ }^{84}$ BOA. DH.ŞFR, 549/98, 28 Mart 1917 (1333); ATASE Arşivi, 320-776-1292-004-01, 1 Nisan 1917 (1333)

${ }^{85}$ BOA. DH.ŞFR, 550/9, 29 Mart 1917 (1333).

${ }^{86}$ BOA. DH.ŞFR, 74/306-1 ve 74/306-2, 29 Mart 1917 (1333).

${ }^{87}$ BOA. DH.ŞFR, 74/305, 29 Mart 1917 (1333).

88 BOA. DH.ŞFR, 550/9, 29 Mart 1917 (1333); BOA. HR.SYS 2436/27, 8 Mayıs 1917 (1333); Emmanuil Emmanuilidis, Osmanlı İmparatorluğunun Son Yilları, Belge Yay., İstanbul 2014, s.162; Persecution of the Greeks in Turkey 1914-1918, s.67.

${ }^{89}$ BOA. DH.ŞFR, 550/29, 31 Mart 1917 (1333).

${ }^{90}$ BOA. DH.ŞFR, 550/24, 31 Mart 1917 (1333); BOA. DH.ŞFR, 75/12, 1 Nisan 1917 (1333); BOA. DH.ŞFR, 75/10, 1 Nisan 1917 (1333). 
Ayvalık'tan çıkarılanların bir kısmı da İzmir Bergama'ya sevk edilecekti. 17. Kolordu Kumandanlığı Rumların Havran - Bergama çevresine sevk edilmesinde mahzur görmüyordu. Buraların dışında bir kısım Rum da liva dahilinde iç kesimlere sevk ediliyordu. 5. Ordu Komutanı Liman von Sanders'in de onayını alan Dahiliye Nezareti, özellikle Karesi Livası dâhiline sevk edilenlerden hükümetten yardım almayanların yasak yerler dışında istedikleri yerlere gitmelerine müsaade ediyordu. ${ }^{91}$ Aynı şekilde Bursa'ya sevk edilenler içerisinde de hükümetten yardım talebinde bulunmayanların Bursa'nın sahil kesimi ile İstanbul ve İzmit dışında istedikleri yerlere gitmelerine müsaade ediliyordu. ${ }^{92}$

Ayvalık'tan 4 Nisan 1917'ye kadar 5063 kişi çıkarılmıştı. Tahliye edilenlerin 4987'si Karesi'ye, 76 kişi Soma'ya gönderilmek üzere Ayazment'e sevk edilmişti. Karesi'ye sevk edilenlerin bir kısmı iskan edilmek üzere Bigadiç, Sındırgı ve Susurluk'a gönderilmişti. Bir kısmı da Karesi merkezde kalmıştı. ${ }^{93} 4$ Nisandan 14 Nisana kadar 4091 kişi daha Ayvalık'tan çıkarılmışt. ${ }^{94} 25$ Nisanda 3947 kişi daha tahliye edilmişti. Bu tahliyeden sonra şehirde dört yüz-beş yüz civarında Rum kalmıştı, onlar da birkaç güne gönderileceklerdi. ${ }^{95}$ Böylece 31 Marttan 25 Nisana kadar olan zaman zarfında 13.101 kişi Ayvalık’tan çıkarılmıştı.

Talat Paşa Bursa ve Aydın Vilayetlerine gönderdiği talimatlarda Ayvalık'tan gönderilenlerin sevk, iskan, güvenlik ve sağlık işlerinin halledilmesi konusunda gerekenin yapılmasını istemişti. ${ }^{96}$ Ancak Bursa, Bilecik ve Yenişehir'e gönderilen Rumlar ciddi sorunlar yaşıyorlar, açlık, sefalet ve ölümle mücadele ediyorlardı ${ }^{97}$ Nakil vasıtaları yetersiz olduğu için çok uzun süre konaklama merkezlerinde beklemek zorunda kalıyorlard1. ${ }^{98}$ Örneğin Bursa'ya sevk edilecek olanların toplanma merkezi Sındırgı'ydı. Ayvalık'ın tahliyesi başlamadan önce Karesi Mutasarrıfı Dahiliye Nezaretine gönderdiği telgrafında, livada Rumların iskan ve iaşelerinin katiyen imkanı olmadığını, kalabalık nedeniyle gönderileceklerin sefil ve perişan olacaklarını ifade etmiști. ${ }^{99}$ Buna rağmen tahliyeler başladığında 8 bin kişiyle en fazla sevk buraya yapılmış ${ }^{100}$ ve sevk edilenler ciddi sorunlar yaşamışlardı. Nakil vasıtası olmadığ için uzun süre iskan mahalleri olan Bursa ve Bilecik'e sevk edilememişlerdi. ${ }^{101}$ Konaklama merkezlerinde uzun süre kalmak zorunda kalan Rumlar açlık ve sefaletin yanında sağlık sorunları da yaşıyorlardı. Susurluk'ta uzun süre beklemek zorunda kalan Rumlar arasında tifüs yayılmıştı. ${ }^{102}$ Kafileler Ayvalık'tan çıkarılırken salgın hastalıklara karşı sağlık kontrollerinden geçiriliyorlar ${ }^{103}$ ve hasta olanlar tedavi ediliyorsa $\mathrm{da}^{104}$ bu tedbirler Rumlar arasında tifüs, lekeli humma ve diğer salgın hastalıkların yayılmasını önlemeye yetmiyordu. ${ }^{105}$

\footnotetext{
${ }^{91}$ BOA. DH.ȘFR, 74/299, 29 Mart 1917 (1333); BOA. DH.ŞFR, 550/69, 2 Nisan 1917 (1333).

${ }^{92}$ BOA. DH.ŞFR, 76/194, 17 Mayıs 1917 (1333).

${ }_{93}^{93}$ BOA. DH.ŞFR, 550/83, 4 Nisan 1917 (1333); BOA. DH.ŞFR, 75/85, 8 Nisan 1917 (1333).

${ }^{94}$ BOA. DH.ŞFR, 551/46, 14 Nisan 1917 (1333).

${ }^{95}$ BOA. DH.ŞFR, 552/66, 25 Nisan 1917 (1333).

${ }^{96}$ BOA. DH.ŞFR, 75/200, 22 Nisan 1917 (1333); BOA. DH.ŞFR, 75-/226, 23/24 Nisan 1917 (1333).

${ }^{97}$ Percutions of the Greek Population in Turkey Since the Beginning of the War, Greek Ministry for Foreign Affairs, London, Constable\&Co.Ltd 1918, s.39-40.

${ }^{98}$ BOA. DH.ŞFR, 550/15, 30 Mart 1917 (1333); BOA. DH.ŞFR 550/19, 30 Mart 1917 (1333); Mihail Rodas, Almanya Türkiye'deki Rumları Nasıl Mahvetti, Belge Yay., İstanbul 2011, s.135-139.

${ }^{99}$ BOA. DH.ŞFR, 549/98, 28 Mart 1917 (1333).

${ }^{100}$ Bayram Bayraktar, Osmanlı'dan Cumhuriyete Ayvalık Tarihi, Atatürk Araştırma Merkezi Yay., Ankara 1998, s. 69.

${ }^{101}$ BOA. DH.ŞFR, 553/19, 1 Mayıs 1917 (1333); BOA. DH.ŞFR, 76/11, 2 Mayıs 1917 (1333); BOA. DH.ŞFR, 76/43, 7 Mayis 1917 (1333); BOA. DH.ŞFR, 552/61, 25 Nisan 1917 (1333).

${ }^{102}$ BOA. DH.SFR, 75/268, 30 Nisan 1917 (1333).

${ }^{103}$ BOA. DH.ŞFR, 550/29, 31 Mart 1917 (1333).

${ }^{104}$ BOA. DH.SFR, 551/117, 19 Nisan 1917 (1333).

${ }^{105}$ BOA. DH.SFR, 75/80, 8 Nisan 1917 (1333).
} 


\begin{abstract}
Sonuç
İttihat ve Terakki hükümeti Yunanistan'ın Balkan Savaşında Ege Adalarını ele geçirerek Batı Anadolu sahillerine iyice yakınlaşmasını Anadolu'nun geleceğini tehdit eden bir durum olarak değerlendiriyordu. Hükümete göre Batı Anadolu'da önemli miktarda Rum nüfusunun yaşıyor olması ve bu Rumların duygusal anlamda kendilerini Yunanistan'a yakın hissetmeleri Yunanistan'ın neden olduğu tehlikenin boyutunu daha da büyütüyordu. Hem Rumların Balkan Savaşında ve Dünya Savaşında Osmanlı Devleti ve Müslüman ahali aleyhine faaliyetleri hem de Yunanistan'ın elindeki Midilli adasına yakınlığı nedeniyle Yunan tehlikesinin en çok hissedildiği yerlerden bir tanesi de Ayvalık'tı. İttihat ve Terakki hükümeti Ayvalık'ın neden olduğu güvenlik probleminin çözümü olarak burada yaşayan Rumları tehcir etme yoluna gitmişti.
\end{abstract}

Ayvalık'ta tehcir ilk olarak 1914 yılında uygulanmıştı. Ülke dışına göç ettirme şeklinde uygulanan bu tehcirle, Ayvalık nüfusunun önemli kısmı Yunanistan'a ve Yunanistan'1n eline geçmiş olan Ege Adalarına göç ettirilmişti. Hükümetin uyguladığı bu gayrı resmi göç ettirme metodunun tatbiki oldukça sıkıntılı ve sancılı olmuştu. Göç ettirme esnasında, Rumlara karş1 hiç de hoş karşılanmayacak uygulamalar yapılmıştı. Meydana gelen olaylar Yunanistan'da çok büyük tepkilere neden olmuştu. Yunan Başbakanı Venizelos savaş notası verince, İttihatçılar Ayvalık Rumlarının göçünü durdurmak zorunda kalmıştı. Bu dönemde Ayvalık nüfusunun üçte biri göç etmişti.

Ayvalıklı Rumlar, I. Dünya Savaşı sırasında da zararlı faaliyetlerini aynı şekilde devam ettirmişlerdi. Çanakkale Boğazında ölüm kalım mücadelesinin verildiği bir savaşta buraya oldukça yakın bir konumda bulunan Ayvalık'ta, meydana gelen zararlı faaliyetler cepheyi tehlikeye atmaktaydı. Bundan dolayı askeriye, özellikle casusluk faaliyetlerini engellemeye çalışıyordu. Ayvalıklı Rumların casusluk yapmaya devam etmeleri, askeriyenin burayı tahliye etmeye karar vermesine neden olacaktı.

1.Dünya Savaşı sırasında Ayvalık'ta uygulanacak tehcirlerde de önemli sorunlar ve sıkıntılar yaşanmıştı. Her şeyden önce tehcir kararının alınmasında sorunlar yaşanıyordu. Devleti yöneten kurumlar arasında fikir aykırılıkları vardı. Askeriye tehcir kararını sivil idarecilere danışmadan kendi başına alıyordu. Askeriyenin almış olduğu tehcir kararları Dahiliye Nezareti ve Karesi Mutasarrıfı tarafından yerinde görülmüyordu. Planlamadaki aksaklıklar da, tehcirin uygulanması sırasında sorunlar yaşanmasına neden oluyordu.

\title{
Kaynakça
}

\section{1-Arşiv Belgeleri*}

A-Devlet Arşivleri Başkanlığı Osmanlı Arşivi (BOA)

\author{
BOA. BEO
}

BOA. DH.ŞFR

BOA. DH.ID

BOA.DH.EUM.EMN

BOA.DH.KMS

BOA. DH.EUM.3.ŞB

\footnotetext{
* Belge numaraları metin içerisinde gösterilmiştir.
} 
BOA. DH.EUM.5.ŞB

BOA. HR.SYS

BOA. HR.H

B-Atase Arşivi, 320-776-1292-004-01

\section{2-Süreli Yayın}

“Talat Beyin Beyanatı”, Ikdam, 11 Haziran 1914 (29 Mayls 1330).

“Atina Ajansından”, İkdam, 14 Haziran 1914 (1 Haziran 1330).

"Yunanın Notası", İkdam, 14 Haziran 1914 (1 Haziran 1330).

“Rumca Gazetelerden”, İkdam 18 Haziran 1914 (5 Haziran 1330).

\section{3-Araştırma ve İnceleme Eserleri}

AKÇAM, Taner, Ermeni Meselesi Hallolmuştur, Osmanlı Belgelerine Göre Savaş Yıllarında Ermenilere Yönelik Politikalar, , İletişim Yay., İstanbul 2008.

BAYAR, Celal, Ben de Yazdım, Baha Mat., 1967.

BAYRAKTAR, Bayram, Osmanlı'dan Cumhuriyete Ayvalık Tarihi, Atatürk Araştırma Merkezi Yay., Ankara 1998.

BİLGİ, Nejdet, Dr. Mehmed Reşid Şahingiray'ın Hayatı ve Hâtıraları-Ittihad ve Terakki Dönemi ve Ermeni Meselesi, Akademi Kitabevi, İzmir 1997.

ÇETINKKAYA, Y. Doğan, Osmanlı'yı Müslümanlaştırmak, İletişim Yayını, İstanbul 2015.

DUMAN, Önder, Emperyal Bir Araç Olarak Rum Pontus Sourunu (1908-1918), Berikan Yayınevi, Ankara 2010.

DÜNDAR, Fuat, Modern Türkye'nin Şifresi Ittihat ve Terakkinin Etnisite Mühendisliği (19131918), İletişim Yay., İstanbul 2008.

DÜNDAR, Fuat, Ittihat ve Terakkinin Müslümanları İskan Politikası (1913-1918), İletişim Yay., İstanbul 2001.

EFİLĞLU, Ahmet, Osmanlı Rumları Göç ve Tehcir 1912-1918, Bayrak Yay., İstanbul 2011.

EMMANUILIDİS, Emmanuil, Osmanlı İmparatorluğunun Son Yılları, Belge Yay., İstanbul 2014.

EROL, Emre, "Eski Foça'nın 'Kara Haziran'1”, Toplumsal Tarih, S.248, Ağustos 2014, s.8690.

EROL, Emre, "Makedonya Sorunu'nun Batı Anadolu’ya Sıçrayışı ve 1914 Rum Tehciri”, Toplumsal Tarih, S. 252, Aralık 2014, s.58-65.

FORTNA, Benjamin C., Kuş̧̧ubaşı Eşref, Efsana Teşkilat-ı Mahsusa Subayının Hayatı, Çev: Selçuk Uygur, Timaş Yay., İstanbul 2018.

HALAÇOĞLU, Ahmet, Balkan Harbi Strasında Rumeli'den Türk Göçleri, TTK Yay., Ankara 1995.

Halil Menteşe 'nin Anıları, Osmanlı Mebusan Meclisi Reisi, Haz.: Orhan Birgit, Hürriyet Vakfı, İstanbul 1986. 
IKDAM, “Atina Ajansından”, 14 Haziran 1914 (1 Haziran 1330)

KARPAT, Kemal H., Osmanl Nüfusu (1830-1914) Demografik ve Sosyal Özellikler, Tarih Vakfi Yurt yay., İstanbul 2003.

KUTAY, Cemal, Etniki Eteryadan Günümüze Ege’nin Türk Kalma Savaşı, Boğaziçi Yay., İstanbul 1980.

PAPADOPOULUS, Alexander, Resmi Belgelerle Avrupa Savaşından Önce Türkiyeli Rumlar üzerindeki Zulüm Pontus Trajedisi 1914-1922 Kara Kitap, Pencere Yay., İstanbul 2013.

Percutions of the Greek Population in Turkey Since the Beginning of the War, Greek Ministry for Foreign Affairs, Constable\&Co.Ltd London 1918.

Persecution of the Greeks in Turkey 1914-1918, Greek Patriarchate, Constantinaoble 1919.

RODAS, Mihail, Almanya Türkiye'deki Rumları Nasıl Mahvetti, Belge Yay., İstanbul 2011.

SANDERS, Liman Von, Türkiye'de Beş Sene, Yeditepe Yay., İstanbul 2006.

SARI, Mustafa, "Birinci Dünya Savaşı'nda Batı Anadolu'da Rumların Casusluk ve Çetecelik Faaliyetleri”, History Studies, Vol. 7, Issue 1, March 2015, s.175-189.

SÖYLEMEZOĞLU, Galip Kemali, Hatıraları Atina Sefareti (1913-1916), Canl Tarihler, Türkiye Yayınları, İstanbul 1946.

TAÇALAN, Nurdoğan, Ege'de Kurtuluş Savaşı Başlarken Hasan Tahsin, Aksoy Yay., İstanbul 1998. 